\title{
Molybdenum application associated with nitrogen fertilization on yield and physiological potential of wheat seeds
}

\author{
Aplicação de molibdênio associada à adubação nitrogenada de \\ cobertura na produtividade e no potencial fisiológico de \\ sementes de trigo
}

\author{
José Henrique Bizzarri Bazzo ${ }^{1 *}$; Denis Santiago da Costa ${ }^{2}$; Thamiris Barbizan ${ }^{3}$; \\ André Prechlak Barbosa ${ }^{1}$; Eli Carlos de Oliveira ${ }^{4}$; Claudemir Zucareli ${ }^{4}$
}

\begin{abstract}
Molybdenum (Mo) is a micronutrient that plays a fundamental role in the assimilation of nitrogen $(\mathrm{N})$ in plants, and top-dressing $\mathrm{N}$ fertilization associated with different forms of molybdenum application can increase the yield and physiological potential of wheat seeds. The objective of this study was to evaluate the yield and physiological potential of wheat seeds treated with different forms of Mo application associated with $\mathrm{N}$ fertilization. The experiment was performed using the wheat cultivar $\mathrm{CD} 150$ in randomized blocks in split plots, with four replicates. Plots were evaluated for four forms of Mo application: $0 \mathrm{~g} \mathrm{ha}^{-1}$ of Mo, seed treatment with $40 \mathrm{~g} \mathrm{ha}^{-1}$ of Mo, foliar treatment with $40 \mathrm{~g} \mathrm{ha}^{-1}$ of Mo, and seed + foliar treatment each at $20 \mathrm{~g} \mathrm{ha}^{-1}$. In the subplots, four $\mathrm{N}$ rates $\left(0,30,60\right.$, and $\left.90 \mathrm{~kg} \mathrm{ha}^{-1} \mathrm{~N}\right)$ were applied at the start of the tillering phase. We evaluated the following parameters: seed yield, mass of one thousand seeds, germination, first germination count, seedling root and shoot length, electrical conductivity, seedling emergence in sand, emergence speed index, and crude and soluble protein contents. The yield of wheat seeds increased with increasing rates of $\mathrm{N}$ in the top-dressing. Nitrogen fertilization associated with different forms of Mo application did not interfere with the crude and soluble protein contents or with any of the parameters related to the physiological potential of wheat seeds.
\end{abstract}

Key words: Molybdenum fertilization. Nitrogen. Protein contente. Triticum aestivum L. Vigor.

\section{Resumo}

A adubação nitrogenada de cobertura associada a diferentes formas de aplicação de molibdênio (Mo), micronutriente que desempenha papel fundamental na assimilação do nitrogênio $(\mathrm{N})$ pelas plantas, pode favorecer a produtividade e o potencial fisiológico das sementes de trigo. Objetivou-se avaliar a produção e o potencial fisiológico de sementes de trigo submetido a diferentes formas de aplicação de Mo associadas à adubação nitrogenada de cobertura. $\mathrm{O}$ experimento foi conduzido com a cultivar CD150, sob o delineamento experimental de blocos casualizados em parcelas subdivididas, com quatro repetições. Nas parcelas foram avaliadas quatro formas de aplicação de Mo $\left(0 \mathrm{~g} \mathrm{ha}^{-1}\right.$ de Mo; $40 \mathrm{~g} \mathrm{ha}^{-1}$ de Mo no tratamento de sementes; $40 \mathrm{~g} \mathrm{ha}^{-1}$ de Mo no tratamento foliar e $20 \mathrm{~g} \mathrm{ha}^{-1}$ de Mo no tratamento

${ }^{1}$ Discente de Doutorado em Agronomia, Pós-Graduação em Agronomia, Universidade Estadual de Londrina, UEL, Londrina, PR, Brasil. E-mail: agro.bazzo@gmail.com

2 Prof., Departamento de Ciências Agrárias, Instituto Federal do Mato Grosso do Sul, IFMS, Nova Andradina, MS, Brasil. E-mail: denis.costa@ifms.edu.br

3 Discente de Doutorado em Agronomia, Pós-Graduação em Agronomia, Universidade Federal da Grande Dourados, UFGD, Dourados, Mato Grosso do Sul, Brasil. E-mail: tha_barbizan@hotmail.com

4 Profs. Drs., Departamento de Ciências Agrárias, UEL, Londrina, PR, Brasil. E-mail: elioliveira.agro@gmail.com; claudemircca@ uel.br

* Author for corespondence 
de semente $+20 \mathrm{~g} \mathrm{ha}^{-1}$ de Mo no tratamento foliar). Nas subparcelas, foram aplicadas quatro doses de $\mathrm{N}$ em cobertura $\left(0,30,60\right.$ e $\left.90 \mathrm{~kg} \mathrm{ha}^{-1} \mathrm{de} \mathrm{N}\right)$, na fase de perfilhamento. Foram avaliados: produtividade de sementes, massa de mil sementes, germinação, primeira contagem de germinação, comprimento de parte aérea e de raiz de plântulas, condutividade elétrica, emergência de plântulas em areia, índice de velocidade de emergência e os teores de proteínas bruta e solúvel das sementes. A produtividade de sementes de trigo aumenta com o incremento das doses de $\mathrm{N}$ em cobertura. A fertilização nitrogenada, as diferentes formas de aplicação de Mo e a associação entre esses fatores não interferem nos teores de proteínas bruta e solúvel ou no potencial fisiológico das sementes de trigo.

Palavras-chave: Adubação molíbdica. Nitrogênio. Teor de proteína. Triticum aestivum L. Vigor.

\section{Introduction}

The productive potential of wheat has been achieved by using nitrogen $(\mathrm{N})$ fertilization, because $\mathrm{N}$ is quantitatively the most important element for the crop, with positive effects on the productivity and quality of grains/seeds (MEGDA et al., 2009).

In this context, well-nourished plants are able to produce more and better quality seeds, which has a positive influence on the establishment of the crop in the field (NASCIMENTO, 2005). According to Carvalho and Nakagawa (2012), nutrient availability affects the chemical composition of seeds, embryo formation, and reserve structures, and consequently the physiological performance of seeds.

The physiological potential of seeds can be influenced by the availability of $\mathrm{N}$, since this nutrient is a structural constituent of many biomolecules in plants that are responsible for various metabolic functions that determine their adequate growth and development (KOLCHINSKI; SCHUCH, 2004; YANO et al., 2005). As Brazilian soils do not fully meet the demand for $\mathrm{N}$ by cultivated species (ERNANI, 2003), their complementation with $\mathrm{N}$ fertilizers is essential.

The $\mathrm{N}$ present in the soil is absorbed mainly in the nitric form, which is subsequently reduced in the plant to ammonia by the actions of nitrate reductase and nitrite reductase enzymes, with the activity of the former being highly dependent on molybdenum (Mo) (TAIZ et al., 2017). Therefore, Mo plays a fundamental role in the process of $\mathrm{N}$ incorporation by plants, since it acts as a cofactor responsible for its assimilation (MARTENS; WESTERMANN, 1991).
Although required in only small quantities, poorly managed soils may not meet plant demand for Mo. In corn, Ferreira et al. (2001) observed that Mo fertilization increased the grain protein content by $3 \%$. According to Marschner (1995), this positive influence of Mo on protein content can be attributed to its influence on the metabolic processes involving $\mathrm{N}$, by increasing nitrate reductase activity and thereby enhancing the incorporation of $\mathrm{N}$ in proteins. Owing to its high mobility in plants and the need for small amounts, Mo can be supplied to the plants through foliar application (RODRIGUES et al., 1997) or via seed treatment (ABREU et al., 2007).

Thus, given the importance of $\mathrm{N}$ and plant responses to $\mathrm{N}$ fertilization, together with the performance of Mo as an enzymatic cofactor in the assimilation of $\mathrm{N}$ by plants, research is necessary to relate these factors in order to generate information on the management of $\mathrm{N}$ fertilizers in wheat crops, and thereby improve seed quality and vigor. Accordingly, the objective of this study was to evaluate the production and physiological potential of wheat seeds treated with different forms of Mo application associated with nitrogen fertilization.

\section{Material and Methods}

The experiment was carried out at the School Farm of Londrina State University (FAZESC-UEL), in the municipality of Londrina-PR, in a eutroferric Red Latosol, located at $23^{\circ} 23^{\prime} \mathrm{S}$ and $51^{\circ} 11^{\prime} \mathrm{W}$, and at an altitude of $566 \mathrm{~m}$. The climate of the region is of type Cfa, described as humid subtropical with hot 
summers, according to the Köppen classification. the records of the meteorological station of the Rainfall and temperature data were obtained from Agronomic Institute of Paraná (Figure 1).

Figure 1. Average temperature and rainfall per 10-day period during conduction of the experiment. S: sowing; T: tillering; H: harvest. Londrina-PR, 2014.

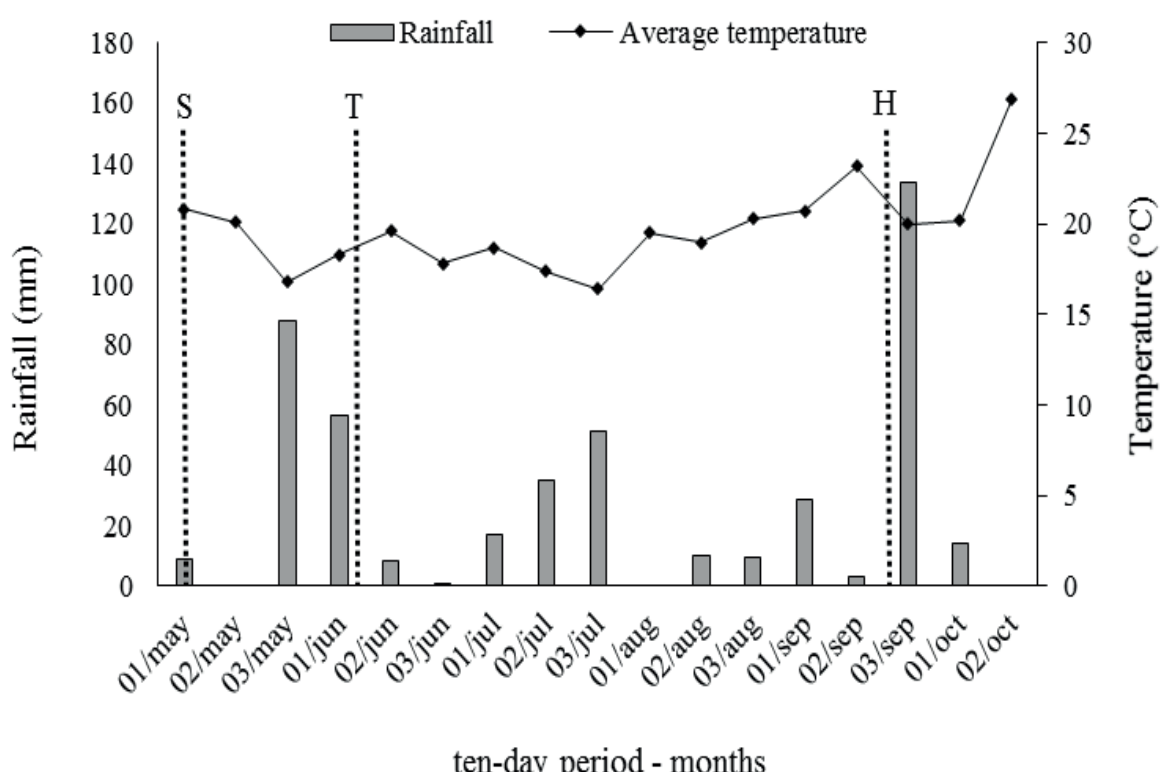

The chemical characteristics of the soil at depths of 0 to $10 \mathrm{~cm}$ and 10 to $20 \mathrm{~cm}$, determined prior to installation of the experiment, were as follows: from 0 to $10 \mathrm{~cm}: \mathrm{pH}\left(\mathrm{CaCl}_{2} 0.01 \mathrm{~mol} \mathrm{~L}^{-1}\right) 5.40,4.96$ $\mathrm{cmol}_{\mathrm{c}} \mathrm{dm}^{-3}$ of $\mathrm{H}^{+}+\mathrm{Al}^{3+}, 7.9 \mathrm{cmol}_{\mathrm{c}} \mathrm{dm}^{-3}$ of $\mathrm{Ca}^{2+}, 0.90$ $\mathrm{cmol}_{\mathrm{c}} \mathrm{dm}^{-3}$ of $\mathrm{Mg}^{2+}, 0.91 \mathrm{cmol}_{\mathrm{c}} \mathrm{dm}^{-3}$ of $\mathrm{K}^{+}, 1.58 \mathrm{mg}$ $\mathrm{dm}^{-3}$ of $\mathrm{P}$, and $26.90 \mathrm{~g} \mathrm{dm}^{-3}$ of organic matter; from 10 to $20 \mathrm{~cm}: \mathrm{pH}\left(\mathrm{CaCl}_{2} 0.01 \mathrm{~mol} \mathrm{~L}^{-1}\right) 5.40,4.61$ $\mathrm{cmol}_{\mathrm{c}} \mathrm{dm}^{-3}$ of $\mathrm{H}^{+}+\mathrm{Al}^{3+}, 7.3 \mathrm{cmol}_{\mathrm{c}} \mathrm{dm}^{-3}$ of $\mathrm{Ca}^{2+}, 1.20$ $\mathrm{cmol}_{\mathrm{c}} \mathrm{dm}^{-3}$ of $\mathrm{Mg}^{2+}, 0.81 \mathrm{cmol}_{\mathrm{c}} \mathrm{dm}^{-3}$ of $\mathrm{K}^{+}, 0.76 \mathrm{mg}$ $\mathrm{dm}^{-3}$ of $\mathrm{P}$, and $20.15 \mathrm{~g} \mathrm{dm}^{-3}$ organic matter.

The wheat cultivar evaluated was CD 150, which has an early cycle, moderate lodging resistance, and improvement-type industrial quality. The experimental design was of randomized blocks in subdivided plots, with four replications. Four forms of Mo application were evaluated in the plots $\left[\mathrm{P}_{1}=\right.$ Control (without Mo); $\mathrm{P}_{2}=$ Seed treatment (40 $\mathrm{g} \mathrm{ha}^{-1}$ of Mo); $\mathrm{P}_{3}=$ Leaf treatment (40 $\mathrm{g} \mathrm{ha}^{-1}$ of Mo); and $\mathrm{P}_{4}$
$=$ seed treatment $\left(20 \mathrm{~g} \mathrm{ha}^{-1}\right.$ of Mo $)+$ Leaf treatment (20 $\mathrm{g} \mathrm{ha}^{-1}$ of Mo)], using potassium molybdate as a source of the micronutrient, with a concentration of $14 \% \mathrm{Mo}$ and $12 \% \mathrm{~K}_{2} \mathrm{O}$ and $1.4 \mathrm{gm}^{-1}$ density. In the subplots, four $\mathrm{N}$ doses were applied as top-dressing $\left(0,30,60\right.$, and $90 \mathrm{~kg} \mathrm{ha}^{-1}$ of $\left.\mathrm{N}\right)$, with urea $(45 \% \mathrm{~N})$ as the source.

The wheat was cultivated under a no-tillage system, in an area previously seeded with maize. On the basis of the soil chemical characteristics of the experimental areas, the basic mineral fertilization applied in the sowing furrows was calculated as 24 $\mathrm{kg} \mathrm{ha}^{-1}$ of $\mathrm{N}, 84 \mathrm{~kg} \mathrm{ha}^{-1}$ of $\mathrm{P}_{2} \mathrm{O}_{5}$, and $48 \mathrm{~kg} \mathrm{ha}^{-1}$ of $\mathrm{K}_{2} \mathrm{O}$, using the formula 8-28-16 in all treatments. Seeding was performed mechanically on May 7 , with a density of 300 viable seeds $\mathrm{m}^{-2}$. The plots were composed of 14 lines of $6 \mathrm{~m}$ in length and between-line spacing of $0.17 \mathrm{~m}$, with a floor area of $5.1 \mathrm{~m}^{2}$. 
Nitrogen fertilization was carried out at the beginning of tillering by broadcasting (phenological stage 2, Feekes scale). The Mo foliar fertilization was performed during the same period, using $\mathrm{CO}_{2}$ pressurized costal spray, with a volume of $200 \mathrm{~L} \mathrm{ha}^{-1}$. For the treatments corresponding to the application of Mo via seeds, the liquid commercial product was applied manually the day before sowing, allowing the seeds to dry in the shade. For this procedure, commercial doses of the product, corresponding to 20 and $40 \mathrm{~g} \mathrm{ha}^{-1}$ of Mo, were used for the respective plots allotted to receive Mo-seed treatment.

Phytosanitary treatments for the control of diseases and other cultural treatments were performed according to need and recommendations for the crop (COMISSÃO BRASILEIRA DE PESQUISA DE TRIGO E TRITICALE, 2015). Harvesting was carried out after the seeds had reached harvest maturation, characterized by hardening of the caryopsis, when the plants were dry and grain had a water content of less than $20 \%$. The following evaluations were performed to determine the productivity and physiological potential of the seeds:

Seed yield: determined by the seed harvest of plants contained in the floor area. After mechanical threshing, the seeds were weighed and data expressed in $\mathrm{kg} \mathrm{ha}^{-1}$, by correcting the water content to $13 \%$.

Mass of one thousand seeds: obtained by counting and weighing eight replicates of 100 seeds per treatment. The mean of these values was multiplied by 10 to obtain the value of the mass of 1,000 seeds (BRASIL, 2009).

Germination: performed with eight replicates of 50 seeds per treatment, on Germitest ${ }^{\circledR}$ towel paper moistened with distilled water, at the proportion of 2.5 times the dry substrate mass. The paper rolls were maintained in a Mangelsdorf-type germinator at a constant temperature of $20{ }^{\circ} \mathrm{C}$. Evaluations were performed at the first four counts (first count) and 8 days (second count) after the test, registering the number of normal seedlings and expressing the results as a percentage (BRASIL, 2009).

Length of aerial part and seedling root: assessed from the sowing of four replicates of 20 seeds per treatment in the upper third of a Germitest ${ }^{\circledR}$ paper sheet, moistened with distilled water at a proportion of 2.5 times the mass of the dry substrate. The paper rolls containing the seeds were maintained for 5 days in a germinator, at $20{ }^{\circ} \mathrm{C}$ in the dark, after which the length of the shoots and roots of the normal seedlings was evaluated using a graduated ruler. The results were expressed in centimeters per seedlings.

Electrical conductivity: performed using the mass system, with four replicates of 50 seeds. The seed mass was initially determined and then the seeds were placed in plastic cups containing $75 \mathrm{~mL}$ of distilled water and maintained at $25{ }^{\circ} \mathrm{C}$. After $24 \mathrm{~h}$ of soaking, the electrical conductivity of the solution was determined, with results expressed in $\mu \mathrm{S} \mathrm{cm}^{-1} \mathrm{~g}^{-1}$ (VIEIRA; KRZYZANOWSKI, 1999).

Seedling emergence in sand: conducted in a greenhouse with four replicates of 50 seeds per treatment, seeded at $3 \mathrm{~cm}$ depth. The sand used was previously washed and then placed in plastic trays. Humidity was maintained with irrigations as needed. Evaluation of the number of normal emerged seedlings was performed on the $15^{\text {th }}$ day, with results expressed as a percentage.

Germination rate index: conducted together with the test of seedling emergence in sand through daily counts of the number of normal seedlings emerged until the stabilization of emergence, according to the formula proposed by Maguire (1962).

Crude protein content: to obtain the protein content of grain, the $\mathrm{N}$ content was initially determined using the Kjeldahl method according to the Association of Official Analytical Chemists (1995), and subsequently the protein content determined, using a conversion factor $(\%$ protein $=$ $\% \mathrm{~N} \times 5.7)$. 
Soluble protein content: determined based on the method described by Bradford (1976). A protein extract was obtained by collecting $0.5 \mathrm{~g}$ of ground beans, which was macerated in a pre-cooled mortar containing $3 \mathrm{~mL}$ of $0.1 \mathrm{M}$ potassium phosphate buffer solution and $\mathrm{pH} 7.5$, and then placed in an Eppendorf tube and centrifuged at 12,000 rpm at 4 ${ }^{\circ} \mathrm{C}$ for $15 \mathrm{~min}$. The optical density of the supernatant was read in a spectrophotometer at a wavelength of $630 \mathrm{~nm}$ and the results expressed as $\mathrm{mg} \mathrm{g}^{-1}$ of fresh mass.

The data were submitted to a normality test (Shapiro-Wilk) and homogeneity (Bartley) of the errors, and subsequently analysis of variance. The effects of $\mathrm{N}$ dose were studied by unfolding in orthogonal polynomials up to the 2 nd degree and the forms of application of Mo by the Tukey test, at 5\% significance. Pearson's correlation was also performed to estimate the relationships between the physiological potential characteristics and protein content (crude and soluble) and seed productivity, at $5 \%$ significance.

\section{Results and Discussion}

There was no significant effect of the forms of Mo application, the doses of $\mathrm{N}$, or the interaction between the factors for the characteristics evaluated; the exception being seed yield, which was influenced by top-dressing $\mathrm{N}$ fertilization (Table 1).

Table 1. Mean square values of the analysis of variance for the characteristics evaluated in wheat according to the forms of application of molybdenum associated with nitrogenous top-dressing fertilization. Londrina-PR.

\begin{tabular}{lccccccccccc}
\hline \multirow{2}{*}{ Source of variation } & \multicolumn{1}{c}{ Characteristics } \\
\cline { 2 - 13 } & SY & MTS & FC & G & APL & RL & EC & ESI & ESS & CP & SP \\
\hline Molybdenum (Mo) & 104546.33 & 1.57 & 2.84 & 0.51 & 0.02 & 1.84 & 0.57 & 0.32 & 27.39 & 5.39 & 1.02 \\
Nitrogen (N) & $1301863.41^{*}$ & 0.07 & 2.89 & 0.30 & 0.92 & 11.96 & 0.02 & 0.27 & 67.39 & 11.08 & 0.03 \\
N-linear & $3819041.33^{* *}$ & 0.03 & 0.78 & 0.53 & 0.79 & 5.51 & 0.01 & 0.03 & 103.51 & 16.64 & 0.03 \\
N-Quadratic & 24698.09 & 0.01 & 0.36 & 0.14 & 1.9 & 0.01 & 0.004 & 0.01 & 95.06 & 0.23 & 0.01 \\
Mo*N & 24657.92 & 0.91 & 5.12 & 1.33 & 0.26 & 2.02 & 0.33 & 0.87 & 169.06 & 4.02 & 0.40 \\
\hline \multicolumn{1}{c}{ CV 1 (\%) } & 33.09 & 6.87 & 4.65 & 1.64 & 8.86 & 8.71 & 6.87 & 12.85 & 12.02 & 26.85 & 17.23 \\
CV 2 (\%) & 14.24 & 3.68 & 2.81 & 1.08 & 9.89 & 19.15 & 3.68 & 8.63 & 12.00 & 25.80 & 8.12 \\
$\quad$ Mean & 1593.84 & 33.34 & 96.58 & 98.89 & 8.96 & 16.70 & 20.20 & 9.21 & 82.28 & 9.04 & 5.39 \\
\hline
\end{tabular}

*: Significant at $5 \%$ by the F-test.

CV 1: coefficient of variation of the plot; CV 2: coefficient of variation of the subplot; SY: seed yield ( $\left.\mathrm{kg}^{-1}\right)$; MTS: mass of one thousand seeds (g); G: germination (\%); FC: first count of germination (\%); APL: aerial part length (cm); RL: root length (cm); EC: electrical conductivity $\left(\mu \mathrm{S} \mathrm{cm}^{-1} \mathrm{~g}^{-1}\right)$; ESI: emergence speed index (\%); ESS: emergence of seedlings in sand (\%); CP: crude protein content (\%); SP: soluble protein $\left(\mathrm{mg} \mathrm{g}^{-1}\right)$.

The wheat seed yield fitted a linear equation, increasing with an increase in $\mathrm{N}$ dose, with a rate of increase of $7.2 \mathrm{~kg} \mathrm{ha}^{-1}$ for each $\mathrm{kg}$ of $\mathrm{N}$ added, giving a yield of approximately $1,928 \mathrm{~kg} \mathrm{ha}^{-1}$ when using the highest dose ( $90 \mathrm{~kg} \mathrm{ha}^{-1}$ of $\mathrm{N}$ ) (Figure 2). Within plants, $\mathrm{N}$ is a component of molecules such as ATP, NADPH, FAD, chlorophyll, amino acids, proteins, nucleic acids, and countless enzymes, acting directly in vital processes such as photosynthesis, respiration, cell proliferation, and differentiation (MALAVOLTA; VITTI; OLIVEIRA, 1997).
According to Soratto et al. (2007), N, because of its multiple functions in the plant, is able to alter the components of crop production and positively influence seed productivity, as observed in this study. Similar results were observed by Kolchinski and Schuch (2003), working with four cultivars of white granulated oats (CTC 5, UFRGS 15, UFRGS 19 , and UPF 18) with four $\mathrm{N}$ doses $(0,24,48$, and $73 \mathrm{~kg} \mathrm{ha}^{-1}$ ) and Bazzo et al. (2016) working with two wheat cultivars (CD 150 and Quartzo), four doses of $\mathrm{N}\left(0,30,60\right.$, and $\left.90 \mathrm{~kg} \mathrm{ha}^{-1}\right)$, and four doses 
of $\operatorname{Mo}\left(0,20,40\right.$, and $\left.60 \mathrm{~g} \mathrm{ha}^{-1}\right)$. However, Teixeira Filho et al. (2010), while evaluating the influence of $\mathrm{N}$ doses and sources on wheat production and productivity components, observed that grain/seed yield was adjusted to a quadratic equation with a maximum efficiency dose estimated at $122 \mathrm{~kg} \mathrm{ha}^{-1}$ of $\mathrm{N}$, which is higher than the maximum evaluated in this study.

An increase in the availability of Mo, either via seed or leaf, did not increase seed yield. As this element is required in small quantities, it is possible that the soil in the area where the experiment was conducted already had an appropriate Mo level for the growth and development of the wheat crop, and thereby indicating that concentrations of Mo above the minimum required by the crop do not result in an increase in the yield of grains/seeds. However, the effects of this nutrient warrant further study, as positive results have been reported for a wheat crop by Zoz et al. (2012), working with cultivar CD104, with an estimated yield of $2,776.25 \mathrm{~kg} \mathrm{ha}^{-1}$ at an Mo dose of $35 \mathrm{~g} \mathrm{ha}^{-1}$.

The different $\mathrm{N}$ doses did not elicit any changes in the physiological potential of seeds or crude and soluble protein contents (Table 1). The absence of an influence of $\mathrm{N}$ fertilization on physiological potential characteristics can occur naturally due to the tendency of plants under conditions of lower nutrient availability to prioritize the preservation of the species, that is, to produce fewer seeds, but with better quality (DELOUCHE, 1980). This could be evidenced by the absence of a significant difference between the means of germination and seed vigor variables (Table 1), even when productivity increased (Figure 2), as well as by the absence of a correlation between productivity and the variables of seed physiology (Table 2). It is noteworthy that, even with an increase in $\mathrm{N}$ dose, there was no increase in the synthesis and assimilation of this element by the seeds in the form of proteins. This indicates that this nutrient may have been preferentially used to enhance vegetative growth of the plant or to increase the number of seeds per area, because there was increase of productivity, without a change in seed mass.

Studies by Kelling and Fixen (1992) have shown that the protein content of the grains/seeds is influenced by the amount of $\mathrm{N}$ absorbed during the plant cycle. Thus, in cereals, protein and starch anabolic pathways compete for photosynthetic products during the grain-/seed-filling period, and when the requirement of $\mathrm{N}$ is satisfied for starch production, the nutrient is used to increase protein concentrations in the grains. Thus, under conditions of $\mathrm{N}$ deficiency in plants, the photoassimilates that would normally be converted into proteins are used in the synthesis of carbohydrates. The same authors report that $\mathrm{N}$ applications at the beginning of the vegetative stage increase the yield of grains/seeds, whereas when applied at more advanced stages they increase the protein content in the grain/seed.

The response of the physiological quality of seeds to $\mathrm{N}$ fertilization is a characteristic that varies depending on the species studied. For example, no effect of $\mathrm{N}$ on quality has been observed for oat (SILVA et al., 2001) and white oat (KOLCHINSKI; SCHUCH, 2004), whereas positive results have been observed by Imolesi et al. (2001) and Bono et al. (2008) in maize seeds, Abrantes et al. (2010) in millet seeds, and Souza et al. (2010) and Smiderle et al. (2011) in rice seeds. 
Figure 2. Seed yield of wheat cultivar CD150 in response to different doses of nitrogen. Londrina-PR, 2014.

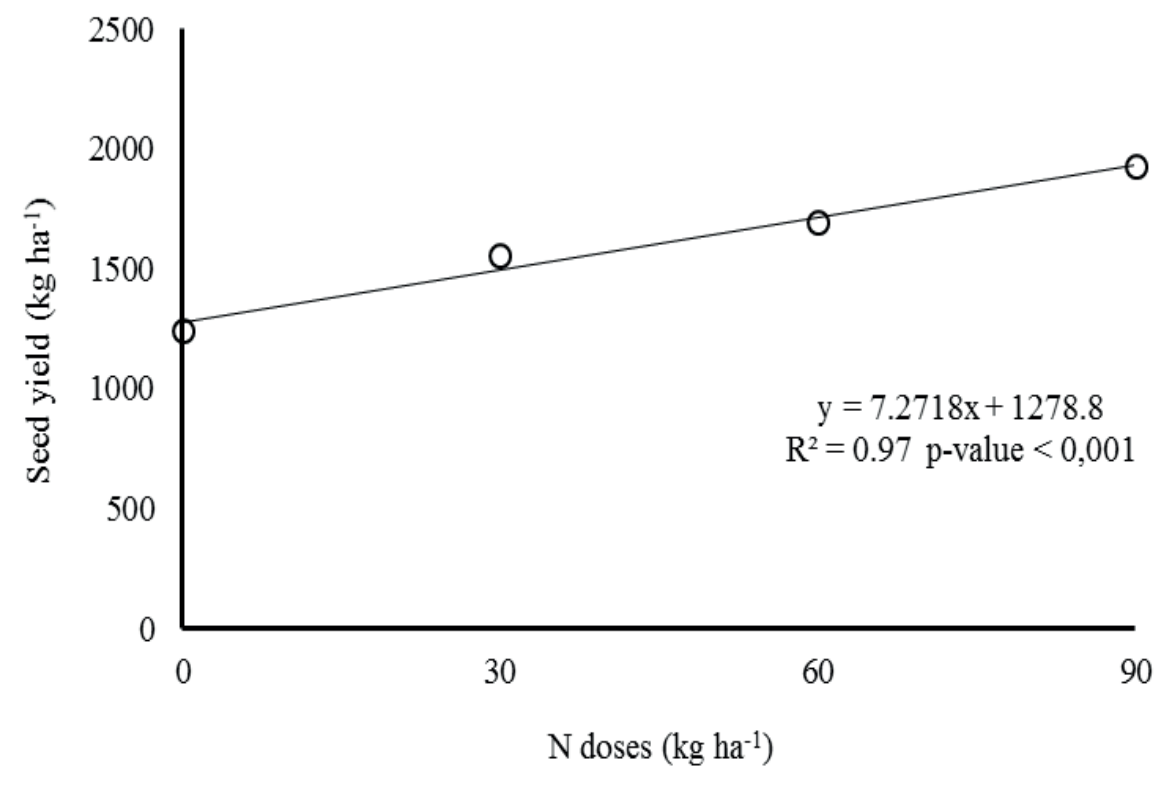

Table 2. Pearson correlation between the mass of one thousand seeds (MTS), germination (G), first count (FC), aerial part length (APL), root length (RL), electrical conductivity (EC), emergence speed index (ESI), emergence of seedlings in sand (ESS) with seed yield (SY), soluble protein content (SP), and crude protein content (CP). LondrinaPR, 2014.

\begin{tabular}{cccccccrr}
\hline & MTS & G & FC & APL & RL & EC & ESI & ESS \\
\hline SY & -0.14 & 0.31 & 0.30 & -0.31 & -0.36 & -0.14 & 0.17 & 0.36 \\
SP & -0.24 & 0.11 & -0.27 & -0.32 & 0.06 & -0.24 & -0.31 & -0.09 \\
CP & 0.20 & 0.37 & 0.20 & -0.36 & 0.36 & 0.20 & 0.31 & 0.06 \\
\hline
\end{tabular}

*: Significant at $5 \%$ by F-test.

As with $\mathrm{N}$, there was no improvement in the physiological potential of seeds with the application of Mo, revealing that supply of this nutrient above the minimum level required by the crop, as well as the form of the supply, do not enhance the physiological potential of wheat seeds (Table 1).

Table 2 shows the absence of a correlation between the crude and soluble protein contents and the other variables of seed quality. These results may be related to the climatic conditions to which the crop was subjected during the period of seed filling, which did not favor the efficient action of $\mathrm{N}$ and/or Mo in terms of protein accumulation, without altering the physiological potential of the seeds. These results may also be related to the fact that the wheat grain/seed reserve is mainly starch (MARCOS-FILHO, 2015), and that the physiological quality of the seeds of this species could be more related to the starch and sugars contents than to protein levels.

\section{Conclusion}

Under the experimental conditions of the present study, the productivity of wheat seeds increased with an increase in the dose of $\mathrm{N}$ top-dressing. 
Nitrogen fertilization, the different forms of Mo application, and the association between the factors did not interfere with the crude and soluble protein contents or the physiological potential of the wheat seeds, and there were no correlations between the evaluated variables.

\section{References}

ABRANTES, F. L.; KULCZYNSKI, S. M.; SORATTO, R. P.; BARBOSA, M. M. M. Nitrogênio em cobertura e qualidade fisiológica e sanitária de sementes de painço (Panicum miliaceum L.). Revista Brasileira de Sementes, Londrina, v. 32, n. 3, p. 106-115, 2010.

ABREU, C. A.; LOPES, A. S.; SANTOS, G. C. G. Micronutrientes. In: NOVAIS, R. F.; ALVAREZ V., V. H.; BARROS, N. F.; FONTES, R. L. F.; CANTARUTTI, R. B.; NEVES, J. C. L. (Ed.). Fertilidade do solo. Viçosa: Sociedade Brasileira de Ciência do Solo, 2007. p. 645736.

ASSOCIATION OF OFFICIAL ANALYTICAL CHEMISTIS - AOAC. Official methods of analysis. 16. ed. Arlington: AOAC, 1995.

BAZZO, J. H. B.; FRACALOSSI, F, P.; ZUCARELI, C.; FONSECA, I. C. B.; BARBOSA, A. P.; SANTOS, R. J. Desempenho produtivo do trigo em resposta a adubação nitrogenada de cobertura e foliar de molibdênio. Semina: Ciências Agrárias, Londrina, v. 37, n. 5, p. 2963-2976, 2016.

BONO, J. A. M.; RODRIGUES A. P. D. C.; MAUAD, M.; ALBUQUERQUE, J. C.; YAMAMOTO C. R.; CHERMOUTH, K. S.; FREITA, M. E. Modo de aplicação de fertilizantes nitrogenados na qualidade fisiológica de sementes de milho. Agrarian, Dourados, v. 1, n. 2, p. 91102, 2008.

BRADFORD, M. M. A rapid and sensitive method for the quantification of microgram quantities of protein utilizing the principle of protein-dye binding. Analitycal Bioche-mistry, Orlando, v. 72, n. 1-2, p. 248-254, 1976.

BRASIL. Ministério da Agricultura, Pecuária e Abastecimento. Regras para análise de sementes. Ministério da Agricultura, Pecuária e Abastecimento. Secretaria de Defesa Agropecuária. Brasília: Mapa/ACS, 2009. 395 p.

CARVALHO, N. M.; NAKAGAWA, J. Sementes: ciência, tecnologia e produção. 5. ed. Jaboticabal: FUNEP, 2012. $590 \mathrm{p}$.
COMISSÃO BRASILEIRA DE PESQUISA DE TRIGO

E TRITICALE. VIII Reunião da comissão brasileira de pesquisa de trigo e triticale. Canela, 2015. Informações técnicas para trigo e triticale: safra 2015. Canela, 2015. $230 \mathrm{p}$.

DELOUCHE, J. C. Environmental effects on seed development and seed quality. Hort Science, Alexandria, v. 15 , n. 6 , p. $775-780,1980$.

ERNANI, P. R. Disponibilidade de nitrogênio e adubação nitrogenada para a macieira. Lages: Graphel, 2003. 76 p.

FERREIRA, A. C. B.; ARAÚJO, G. A. A.; PEREIRA, P. R. G.; CARDOSO, A. A. Características agronômicas e nutricionais do milho adubado com nitrogênio, molibdênio e zinco. Scientia Agricola, Piracicaba, v. 58, n. 1, p. 131-138, 2001.

IMOLESI, A. S.; VON PINHO, E. V. R.; PINHO, R. G. V.; VIEIRA, M. G. G. C.; CORRÊA, R. S. B. Influência da adubação nitrogenada na qualidade fisiológica das sementes de milho. Ciência e Agrotecnologia, Lavras, v. 25, n. 5, p. 1119-1126, 2001.

KELLING, K. A.; FIXEN, P. E. Soil and nutrient requeriments for oat production. In: MARSHALL, H. G.; SORRELIS, M. E. (Ed.). Oat science and technology. Madison: ASA/CSSA, 1992. p. 165-190.

KOLCHINSKI, E. M.; SCHUCH, L. O. B. Atributos de desempenho industrial e qualidade de sementes em aveia branca em função da disponibilização da adubação nitrogenada. Ciência Rural, Santa Maria, v. 33, n. 3, p. 587-589, 2003.

KOLCHINSKI, E. M.; SCHUCH, L. O. B. Relações entre a adubação nitrogenada e a qualidade de grãos e de sementes em aveia branca. Ciência Rural, Santa Maria, v. 34, n. 2, p. 379-383, 2004.

MAGUIRE, J. D. Speed of germination-aid in selection and evaluation for seedling emergence and vigor. Crop Science, Madison, v. 2, n. 1, p. 176-177, 1962.

MALAVOLTA, E.; VITTI, G. C.; OLIVEIRA, S. A. Avaliação do estado nutricional da planta: princípios e aplicações. Piracicaba: POTAFOS, 1997. 319 p.

MARCOS-FILHO, J. Fisiologia de sementes de plantas cultivadas. Londrina: ABRATES, 2015. 659 p.

MARSCHNER, H. Mineral nutrition of higher plants. London: Academic Press Limited, 1995. 889 p. 
MARTENS, D. C.; WESTERMANN, D. T. Fertilizers application for correcting micronutrients deficiencies. In: MORTVEDT, J. J.; COX, F. R.; SHUMAN, L. M.; WELCH, R. M. (Ed.). Fertilizers applications for correcting micronutriente deficiencies: micronutrients in agriculture. 2. ed. Madison: Soil Science Society of America, 1991. p. 549-592.

MEGDA, M. M.; BUZETTI, S.; ANDREOTTI, M.; TEIXEIRA FILHO, M. C. M.; VIEIRA, M. X. Resposta de cultivares de trigo ao nitrogênio em relação às fontes e épocas de aplicação sob plantio direto e irrigação por aspersão. Ciência e Agrotecnologia, Lavras, v. 33, n. 4, p. 1055-1060, 2009.

NASCIMENTO, W. M. Produção de sementes de hortaliças para a agricultura familiar. Brasília: Embrapa Hortaliças, 2005. 15 p. (Circular técnica, 35).

RODRIGUES, L. A.; SOUZA, A. P.; MARTINEZ, H. E. P.; PEREIRA, P. R. G.; FONTES, P. C. R. Absorção e translocação de zinco em feijoeiro aplicado via foliar. Revista Brasileira de Fisiologia Vegetal, Campinas, v. 2, n. 9, p. 11-15, 1997.

SILVA, R. H.; ZUCARELI, C.; NAKAGAWA, J.; SILVA, R. A.; CAVARIANI, C. Doses e épocas de aplicação do nitrogênio na produção e qualidade de sementes de aveia-preta. Revista Brasileira de Sementes, Londrina, v. 23, n. 2, p. 51-55, 2001.

SMIDERLE, O. J.; CHANG, M. T.; FERREIRA, G. B.; CORDEIRA, A. C. C. Qualidade de sementes de arroz BRS Jaçanã em função de aplicações de nitrogênio. Revista Acadêmica: Ciências Agrárias e Ambientais, Curitiba, v. 9, n. 1, p. 79-86, 2011.
SORATTO, R. P.; CARDOSO, S. M.; SILVA, A. H.; COSTA, T. A. M.; PEREIRA, M.; CARVALHO, L. A.; Doses e épocas de aplicação de nitrogênio em cobertura na cultura do painço (Panicum miliaceum L.). Ciência e Agrotecnologia, Lavras, v. 31, n. 6, p. 1661-1667, 2007.

SOUZA, L. C. D.; SÁ, M. E.; MARTINS, H. S. D.; ABRANTES, F. L.; SILVA, M. P.; ARRUDA, N. Produtividade e qualidade de sementes de arroz em resposta a doses de calcário e nitrogênio. Revista Trópica, Chapadinha, v. 4, n. 2, p. 27-35, 2010.

TAIZ, L.; ZEIGER, E.; MOLLER, I. M.; MURPHY, A. Fisiologia e desenvolvimento vegetal. Porto Alegre: Artmed, 2017. 888 p.

TEIXEIRA FILHO, M. C. M. T.; BUZETTI, S.; ANDREOTTI, M.; ARF, O.; BENETT. C. G. S. Doses, fontes e épocas de aplicação de nitrogênio em trigo irrigado em plantio direto. Pesquisa Agropecuária Brasileira, Brasília, v. 45, n. 8, p. 797-804, 2010.

VIEIRA, R. D.; KRZYZANOWSKI, F. C. Teste de condutividade elétrica. In: KRZYZANOWSKI, F. C.; VIEIRA, R. D.; FRANÇA NETO, J. B. F. Vigor de sementes: conceitos e testes. Londrina: ABRATES, 1999. p. 1-26.

YANO, G. T.; TAKAHASHI, H. W.; WATANABE, T. S. Avaliação de fontes de nitrogênio e épocas de aplicação em cobertura para o cultivo do trigo. Semina: Ciências Agrárias, Londrina, v. 26, n. 2, p. 141-148, 2005.

ZOZ, T.; STEINER, F.; TESTA, J. V. P.; SEIDEL, E. P.; FEY, R.; CASTAGNARA, D. D.; ZOZ, A. Foliar fertilization with molybdenum in wheat. Semina: Ciências Agrárias, Londrina, v. 33, n. 2, p. 633-638, 2012. 
